\title{
Extent of Reduction of the Fallow Period and Its Impact on Upland Rice Production in the Nongowa Chiefdom of Kenema District in Eastern Sierra Leone
}

\author{
Alie Kamara1, Osman Sidie Vonu², John Lansana ${ }^{2}$, Foday Saidu Sesay ${ }^{1}$ \\ ${ }^{1}$ Department of Soil Science, School of Agriculture, Njala Campus, Njala University, Njala, Sierra Leone \\ ${ }^{2}$ Department of Agriculture, Eastern Polytechnique, Kenema, Sierra Leone \\ Email: aliekamara@njala.edu.sl
}

How to cite this paper: Kamara, A., Vonu, O.S., Lansana, J. and Sesay, F.S. (2016) Extent of Reduction of the Fallow Period and Its Impact on Upland Rice Production in the Nongowa Chiefdom of Kenema District in Eastern Sierra Leone. Agricultural Sciences, 7, 805-812.

http://dx.doi.org/10.4236/as.2016.711073

Received: August 13, 2016

Accepted: November 20, 2016

Published: November 23, 2016

Copyright $\odot 2016$ by authors and Scientific Research Publishing Inc. This work is licensed under the Creative Commons Attribution International License (CC BY 4.0).

http://creativecommons.org/licenses/by/4.0/

(c) (i) Open Access

\section{Abstract}

Slash-and-burn agriculture is the common practice for upland rice intercropping system in Sierra Leone and it has been blamed for the loss of forest vegetation across the country. Shortening of the fallow period in the Eastern region of Sierra Leone has implications on agricultural food production and the persistence of the remaining tropical rainforest. This study was therefore undertaken to assess: 1) the extent of reduction of the fallow period in the Nongowa Chiefdom of Kenema District; 2) the causes of reduction in the fallow period; 3 ) farmers' perception of the relevance of fallow period and the implications of reduction of fallow period on crop production. The study revealed a drastic reduction of the fallow period in the chiefdom with a mean of 3.8 years which falls far below the country mean fallow period of 8.8 years as estimated by FAO. Farmers pointed out that the reduction of the fallow period was as a result of land scarcity due to competing land uses such as large scale commercial agriculture, logging, mining, charcoal burning and expansion of settlements. Farmers agreed that a fallow period of at least 10 years is necessary for upland rice production. Farmers were aware of the impact of reduction of the fallow period on upland rice production and were able to estimate rice yields based on the age of the fallow. Also, farmers have attempted to adapt to the constraints posed by shorter fallow periods by selection of rice varieties to suit the length of the fallow periods.

\section{Keywords}

Shifting Cultivation, Slash-and-Burn, Fallow Period, Upland Rice Farming, Nongowa Chiefdom, Eastern Sierra Leone 


\section{Introduction}

Shifting cultivation or slash-and-burn agriculture is a global agricultural practice that affects an estimated arable land area of 1500 million ha [1]. It is the traditional method of upland rice cultivation in most parts of West Africa and in the humid and sub-humid tropics. This is a practice where a piece of forest is cleared and burnt for cultivation for a period of two to three years without fertilizer input and then leaving the land under natural fallow vegetation for a much longer period, usually greater than fifteen years, to restore soil fertility [2].

At the onset of the cropping phase, when vegetation is burnt, almost all biomass carbon which is a potential source of soil organic carbon is lost as well as a significant amount of nutrients such as nitrogen and sulphur contained in the biomass [1] [3]. During the cropping phase, inappropriate soil management practices could lead to accelerated depletion of soil organic matter and nutrients resulting in rapid depletion of soil fertility.

During the fallow, the accumulation of biomass on the soil surface and its gradual decomposition does not only release nutrients but provide an energy source for the soil microbial populations and improvement of soil aggregate stability and structure, bulk density, infiltration capacity, cation exchange capacity, and soil organic matter. Also, nutrients are taken up from deeper layers by roots of trees and shrubs and returned to the top soil via litter fall and root senescence.

Restoration of soil fertility by this means requires several years of fallow and has become inadequate in the face of increasing populations and food demand as well as competing alternative land uses. This has led to considerable reduction in the fallow period and the cultivation of marginal lands.

In Sierra Leone, the uplands account for about $80 \%$ of the total arable land. The bush fallow system is a very common farming practice on the uplands of Sierra Leone although it is also practiced in almost all agroeclogies. Upland rice farming system involves intercropping rice with a variety of other crops such as cassava, maize, sorghum, sesame, pigeon pea, okra, garden egg, and other leafy vegetables. Rice normally occupies about $50 \%$ of the cropland [4]. The limitation of this system as a sustainable farming practice is the increasing decline in the fallow period. Generally, the length of fallow period is reported to differ across the country with a mean of 8.8 years [5]. In recent times, it is reported that the fallow period has dropped from the recommended period of ten or more years [6] to about 5 years in rural areas and $3-4$ years along major highways [4].

Apart from the FAO/UNDP survey in 1979 which estimated an average fallow period of 8.8, there has been very little work done to update information on length of fallow period in different parts of the country. There is lack of information on the current extent of reduction in fallow period in different parts of the country particularly in the eastern region of Sierra Leone which is home to the remaining rainforest of the country. The continued decline in the fallow period is a major threat to the persistence of the rainforest in the eastern region of Sierra Leone as farmers are tempted to slash-and- 
burn the remaining forest for upland rice farming. An understanding of the extent of reduction in fallow period in the Eastern Region of Sierra Leone will throw light on the magnitude of the problem and inform policy makers and land use planners to enable them develop intervention strategies to counteract the negative impact of the practice. This study was therefore conducted to determine: 1) the extent of reduction of the fallow period in the Nongowa Chiefdom of Kenema District; 2) the causes of reduction in the fallow period; 3) farmers' perception of the relevance of fallow period and the implications of reduction of fallow period on crop production.

\section{Methodology}

\subsection{Description of the Study Area}

The study area, Nongowa Chiefdom, is located in the Kenema District and it is the largest Chiefdom amongst the sixteen (16) Chiefdoms in the District (Figure 1). The chiefdom is home to the largest city in the eastern region, Kenema City which is also the Headquarter of the Eastern Province of Sierra Leone. Consequently, it is the most populated chiefdom in the District. Kenema City is located about 197 miles from the Capital City, Freetown.

Kenema district has a shorter dry season (December to March) and a longer rainy season (April-November) compared to the most parts of Sierra Leone. Rainfall is mono- modal with a peak in July and August. The average annual rainfall for Kenema

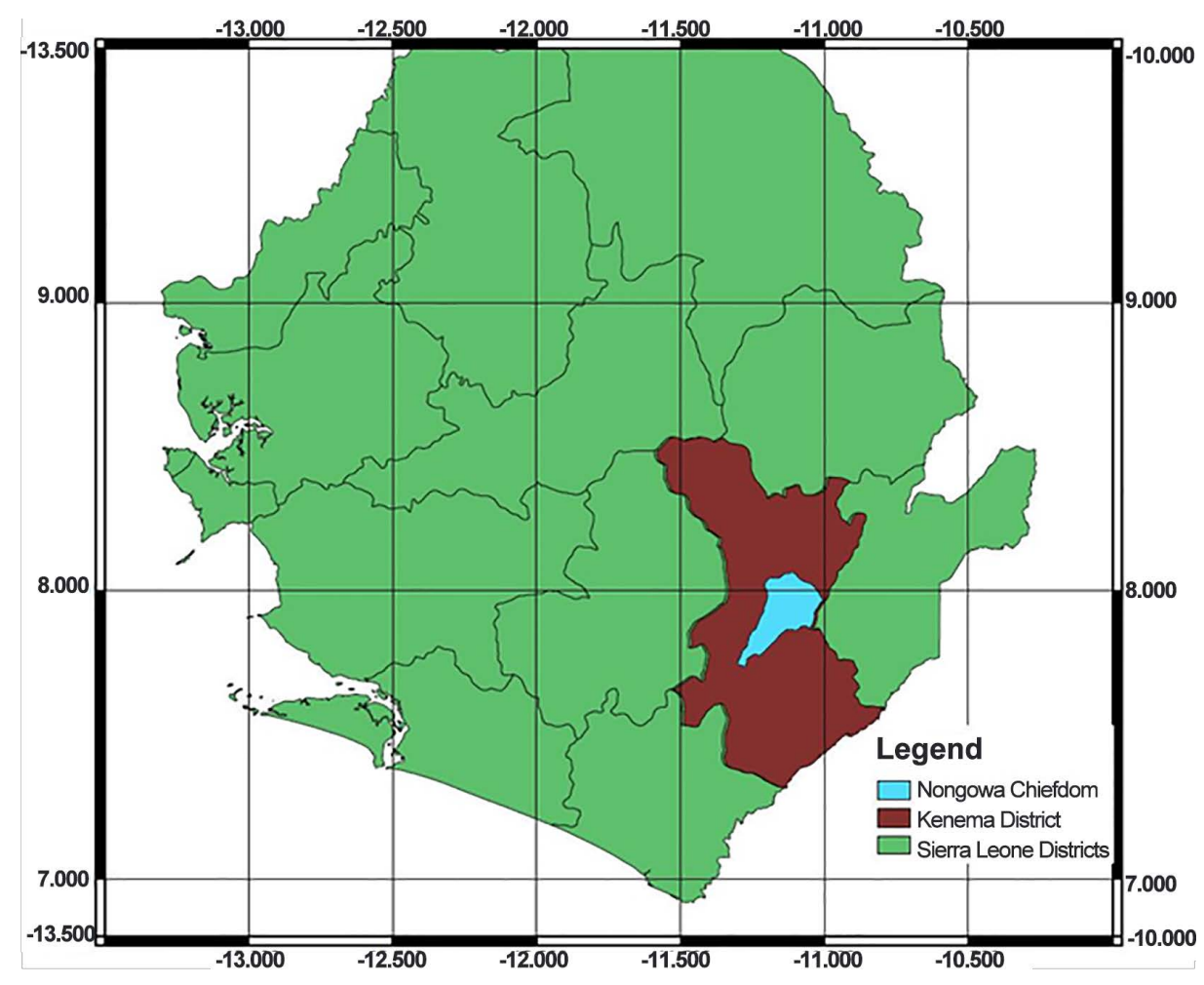

Figure 1. Map (LatLon) showing study location, Nongowa Chiefdom of Kenema District in Eastern Sierra Leone. 
District is $2618 \mathrm{~mm}$ and most of it falls between June and October. In the Nongowa Chiefdom of Kenema District, most of the tropical rainforest has been reduced to secondary forest which is currently the major vegetation cover. Slash-and-burn agriculture is the predominant rice farming system on the uplands and is strictly rainfed.

\subsection{Design of Study and Sample Size}

Sierra Leone is divided into four administrative blocks: the Provinces, the Districts, the Chiefdoms, and the Sections in decreasing sizes and administrative authority respectively. The study was conducted in four (4) Sections of the Nongowa Chiefdom: Gbo Lambayama, Gbo Kakajama, Kagbado Kamboima and Dagbanya. These sections were selected based on the dominant practice of upland rice farming. The natural vegetation in these communities consists of secondary forest or farm bush with small trees or shrubs as a result of frequent felling of trees for farming. In each Section, a list of farmers practising slash-and-burn agriculture on the uplands was prepared and a total of twenty farmers were randomly selected from the list by balloting. In total, eighty farmers were randomly selected for the study in the four Sections of Nongowa Chiefdom.

\subsection{Data Collection and Analysis}

A semi-structured recording schedule (SRS) was used as survey instrument to solicit information from the total of eighty farmers (twenty from each Section) who were randomly selected from the four selected sections in the Chiefdom. The instrument was pre-tested to ensure its validity and reliability. Data was collected between May and September, 2014 using the designed SRS through direct interviews and recording of information solicited from farmers. Data analysis was done in SPSS.

\section{Results and Discussion}

\subsection{Characteristics of Farmers}

Most of the eighty farmers interviewed were males (65/80, i.e. $81.3 \%)$ and few were females $(15 / 80$, i.e. $18.7 \%)$ giving a clear indication that upland rice farming is a male dominated practice. The majority of farmers in the study area were youth mostly below 30 years $(35 / 80$, i.e. $43.8 \%)$ and middle aged men between 30 and 50 years $(40 / 80$, i.e. $50.0 \%)$ and only about 5 out of $80(6.2 \%)$ were above 50 years. Although upland rice farming is known to be male dominated in terms of overall activity and ownership, there are gender and age differences in the distribution of tasks, roles and responsibilities [4].

The marital status of farmers ranged from married (35/80, 43.8\%), single (20/80, $25 \%)$, divorced $(10 / 80,12.5 \%)$, separated $(5 / 80,6.2 \%)$, and widowed $(10 / 80,12.5 \%)$. Most (64/80, i.e. $80 \%)$ of the farmers have been involved in farming for 16 - 20 years.

\subsection{Extent of Reduction of the Fallow Period in the Nongowa Chiefdom of Kenema District}

Information relating to the extent of reduction of fallow was captured from farmers by 
their responses to questions on the different ages of bushes cleared for upland rice farming in their areas, including the length of time they normally allow land to fallow. Analysis of their responses revealed that most farmers (44/80, i.e. 55\%) cultivated lands that have been fallowed for periods between 1 - 2 years (Figure 2). About 41.6\% (33/ $80), 2.6 \%(2 / 80)$ and $1.3 \%(1 / 80)$ (farmers admitted cultivation bushes that have been fallowed for 3 - 4 years, 5 - 10 years and 11 - 20 years respectively (Figure 2). Thus, the majority of farmers in the Nongowa chiefdom, about $96 \%$ (77/80), have been cultivating bushes fallowed for less than five years. The average fallow period for the study area was calculated to be 3.8 years which is well below the country mean fallow period of 8.8 years reported by [5]. This is a clear indication of drastic reduction of the fallow period in the Nongowa Chiefdom of Kenema District.

Since only a very small percentage of the farmers (1.3\%) interviewed were cultivating bushes of long fallow periods ( $11-20$ years), it is apparent that there is stiff competition for these lands and only the affluent in those communities could have access.

\subsection{Causes of Reduction in the Fallow Period}

Farmers' interviewed revealed that the reduction of the fallow period is affected by the general level of development of the community. As the community grows in size, the corresponding increase in economic activities results in more land being used for settlements and construction of infrastructure. Additionally, the advent of investors coming to acquire land for large scale agriculture has led to less land becoming available for cultivation. Consequently, for the remaining portion of lands to which farmers have been confined, the fallow period becomes increasingly shortened or reduced and people begin to move from one community to another in search of lands that have fallowed long enough for crop cultivation. Human activities such as mining, logging and cutting down of forest trees for poles, fuel wood and charcoal production were also identified by farmers as competing alternative land use practices that have had serious effects on the farming communities in terms of land availability.

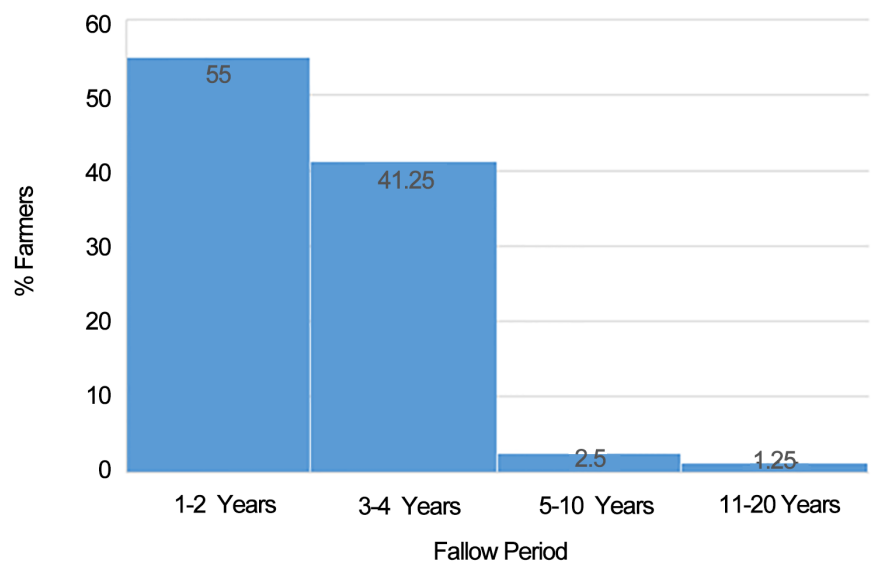

Figure 2. Proportion of farmers cultivating lands of different fallow periods in the Nongowa Chiefdom of Kenema District in Eastern. 
Although historical evidence seemed to blame shifting cultivation for much of deforestation in the tropics [7], evidence from this study showed that other competing land uses such as mining, commercial agriculture, logging and charcoal production have a dominant effect in recent times. This finding support the reports of [8] [9] and [10] that much evidence now exists to show that shifting cultivation is not the main driver of deforestation but commercial agriculture and other drivers are now accountable for most of the recent deforestation in the tropics. In this study, competing land uses such as commercial agriculture or the advent of large-scale investors in agriculture in recent times, as well as investments in mining and timber logging, have restricted farmers to cultivating lands of very short fallow periods ( $<5$ years).

Further analysis of farmers' responses revealed that most of the lands that are subjected to shorter fallow periods are those around towns and major roads and the length of fallow period increased with distance from the towns. This corroborates the report of [4] that the fallow period is considerably reduced along major highways. The reasons given for the reduction in fallow periods around settlements were: 1) the proximity to towns and major roads provide easy access to farm lands for the daily activities of farmers and 2) easy access to markets along major roads because vehicles plying the roads stop by to allow passengers buy produce displayed along the roads.

\subsection{Farmers' Perception of the Relevance of Fallow Period and the Implications of Reduction of Fallow Period on Crop Production}

Farmers accepted that a long fallow period of about ten or more years is considered adequate for cultivation. This indigenous knowledge of farmers on the length of fallow is in agreement with the finding of [11] that the length of the fallow period should not be less than 10 years for a productive shifting cultivation. Farmers understood the effects of fallow periods on crop production and were able to proedict estimates of the different lengths of fallow period may affect crop yields (Table 1).

Although [7] reported that the fallow period is not a good predictor of yields, farmers in the study area seem to be aware of the yields they will expect by cultivation fallowed land of different ages. For young fallows of between 1 and 4 years, the yields are low. As age of the bush increases, the expected yield increases. Higher yields are expected for

Table 1. Farmers' classification of the fallow period and its effect on crop yields.

\begin{tabular}{ccccc}
\hline Classification of & * $\begin{array}{c}\text { Length of Fallow } \\
\text { period (years) }\end{array}$ & Effect on crops & $\begin{array}{c}\text { No. of bushels } \\
\text { planted }\end{array}$ & $\begin{array}{c}\text { No. of bushels } \\
\text { harvested }\end{array}$ \\
\cline { 4 - 5 } Very short & $1-2$ & Very low yield & 1 & 1.5 \\
Short & $3-4$ & Low yield & 1 & 2.0 \\
Medium & $5-10$ & Moderate & 1 & 2.5 \\
Long & $11-15$ & High yield & 1 & 6.0 \\
Very long & $15-20$ & Very high yield & 1 & $12-14$ \\
\hline
\end{tabular}

${ }^{*}$ Period of fallow based on farmers' ideas. 
longer fallow periods of 15 - 20 years when farmers expected 12 - 14 bushels of rice for every one bushel planted. Additionally, farmers reported that there are selected rice varieties for use depending on the fallow period. For short or young fallows, farmers planted local or "Pa Kiamp" improved rice varieties. For medium fallow periods, farmers planted Pa Kiamp and ROK3 improved varieties while for long fallow periods, farmers planted NERICA and ROK3. Thus, this study revealed an interesting varietal selection by farmers as an adaptation to the soil fertility constraints posed by shortening of the fallow period.

In a report on farmers' assessment of rice varieties in Northern Sierra Leone, [12] showed that the majority of farmers have selected Pa Kiamp among the improved varieties in addition to their local varieties for upland rice cultivation. The results of this study indicated that Pa Kiamp is also popular among farmers in the Eastern Sierra Leone and the reason for its popularity is due to its ability to grow under the impoverished soil conditions posed by short fallow periods. The majority of farmers $(44 / 80$, i.e. $55 \%)$ in this study reported cultivating land under very short fallow periods (1 - 2 years), and in the absence of fertilizer application, it is apparent that local rice varieties and $\mathrm{Pa}$ Kiamp among the improved varieties have been selected for use.

\section{Conclusion}

This study has shown that there has been considerable reduction in the bush fallow period in the Nongowa Chiefdom of Kenema District with an average of 3.8 years which is well below the national average. Most farmers in Nongowa Chiefdom cultivate lands that have been followed for less than five years. Competing land uses such as commercial agriculture, logging, mining and charcoal burning have increased land scarcity that has forced farmers to shorten the fallow period thereby making the practice of slash-and- burn agriculture no longer sustainable. The study revealed that farmers are aware of the effects of shorter fallow periods on crop yields and farmers have selected rice varieties that are suitable for cultivation on lands of varying fallow lengths. It is apparent that farmers in the Nongowa Chiefdom are shifting towards sedentary farming, and alternative farming approaches with improved and sustainable soil fertility management practices will be required to improve crop productivity.

\section{Acknowledgements}

We thank our colleagues from both Njala University and Eastern Polytechnic who provided their expertise (opinions and comments) that greatly assisted this work. Also, we would like to express our gratitude to the people of the Nongowa Chiefdom, especially those farmers who provided us with the information needed for the success of this work.

\section{References}

[1] Giardina, C.P., Sanford, R.L., Dockersmith, I.C. and Jaramillo, V.J. (2000) The Effects of Slash Burning on Ecosystem Nutrients during the Land Preparation Phase of Shifting Cul- 
tivation. Plant Soil, 220, 247-260. https:/doi.org/10.1023/A:1004741125636

[2] Nounamo, L. and Yemefack, M. (2000) Shifting Cultivation in Evergreen Forest of Southern Cameroon: Farming Systems Description and Soil Degradation. Final Report, TropenBoss Cameroon, Report 00-2.

[3] Hughes, R.F., Kau Vman, J.B. and Cummings, D.L. (2000) Fire in the Brazilian Amazon 3. Dynamics of Biomass, C, and Nutrient Pools in Regenerating Forests. Oecologia, 124, 574588. https:/doi.org/10.1007/s004420000416

[4] Jalloh, A. (2006) Farming Systems/Agricultural Land Use in Sierra Leone. Land Use Planning for Optimizing Agricultural Production Project (TCP/SIL/3101(A)). Submitted to FAO, Freetown Sierra Leone.

[5] FAO/UNDP (1979) Vegetation and Land Use in Sierra Leone: A Reconnaissance Survey. AG:DP/SIL/73/002.Tehnical Report 2.

[6] MAFS/MMR (2004) Agricultural Sector Review and Agricultural Development Strategy. Volume 1, Main Report, Ministry of Agriculture and Food Security/Ministry of Marine Resources, MAFS/MFMR. Freetown, Sierra Leone.

[7] Mertz, O., Wadley, R.L., Nielsen, U., Bruun, B.T., Col-fer, C.J.P., de Neergaard, A., Jepsen, M.R., Martinussen, T., Zhao, Q., Noweg, G.T. and Magid, J. (2008) A Fresh Look at Shifting Cultivation: Fallow Length and Uncertain Indicator of Productivity. Agricultural Systems, 96, 75-84. https:/doi.org/10.1016/j.agsy.2007.06.002

[8] Defries, R.S., Rudel, T., Uriarte, M. and Hansen, M. (2010) Deforestation Driven by Urban Population Growth and Agricultural Trade in the Twenty-First Century. Nature Geoscience, 3, 178-181. https:/doi.org/10.1038/ngeo756

[9] Rudel, T.K., Defries, R.S., Asner, G.P. and Laurance, W.F. (2009) Changing Drivers of Deforestation and New Opportunities for Conservation. Conservation Biology, 23, 1396-1405. https:/doi.org/10.1111/j.1523-1739.2009.01332.x

[10] Geist, H. and Lambin, E. (2002) Proximate Causes and Underlying Driving Forces of Tropical Deforestation. BioScience, 52, 143-150. https:/doi.org/10.1641/0006-3568(2002)052[0143:PCAUDF]2.0.CO;2

[11] Osman, K.S., Jashimuddin, M., Haque, S.M.S. and Miah, S. (2013) Effect of Shifting Cultivation on Soil Physical and Chemical Properties in Bandarban Hill District, Bangladesh. Journal of Forestry Research, 24, 791-795. https:/doi.org/10.1007/s11676-013-0368-3

[12] Spencer, D. (2010) Farmers Assessment of Rice Varieties in Northern Sierra Leone. Report of a Survey for CARE, 13 October 2010.

http://www.eds-sl.com/docs/FarmersAssessmentofRiceVarietiesinNorthernSierraLeone.pdf 
Submit or recommend next manuscript to SCIRP and we will provide best service for you:

Accepting pre-submission inquiries through Email, Facebook, LinkedIn, Twitter, etc. A wide selection of journals (inclusive of 9 subjects, more than 200 journals)

Providing 24-hour high-quality service

User-friendly online submission system

Fair and swift peer-review system

Efficient typesetting and proofreading procedure

Display of the result of downloads and visits, as well as the number of cited articles

Maximum dissemination of your research work

Submit your manuscript at: http://papersubmission.scirp.org/

Or contact as@scirp.org 